\title{
Preliminary study towards eco-design of housing in coastal settlements in Surabaya (Case study of fishermen housing design after the development of Kenjeran Bridge, Surabaya)
}

\author{
Dewi Septanti ${ }^{a^{*}}$, Rika Kisnarini ${ }^{\mathrm{a}}$, Purwanita Setijantia ${ }^{\mathrm{a}}$, Ayi Syaeful Bahri ${ }^{\mathrm{a}}$, Wahyu Setyawan ${ }^{\mathrm{a}}$ \\ ${ }^{a}$ Department of Architecture, Institut Teknologi Sepuluh Nopember, Kampus ITS Sukolilo, Surabaya, Indonesia \\ *Corresponding author. Tel: +62 8155145437; +62 -31 5924301 \\ E-mail address: dewi_s@arch.its.ac.id
}

\begin{abstract}
This paper involves a discourse about design based research and the research itself. To capture the goals, the issues of this paper are how to re-design the housing surrounding the bridge which built for tourism reason ecologically. In order to improve the quality of the area surrounding the bridge and due to support the tourism and human life, this study would like to investigate the issues about the improvement of settlements quality related to their impact of post construction of the bridge. The study focused on the households' requirements for functionality of houses especially to support tourism and business activities at home. Although several studies on coastal housing problems have been conducted widely, investigation on sustainability of the building is still limited. In term of method, this study was design as an explorative, descriptive, ex-poste and evaluation study. By using the in- depth interviews method, the idea, hope, expectation of inhabitants was gained. 30 respondents were taken from 3 local sub district area. The results showed that the households' needs can be observed through their activities. Households' activities determine their requirements for the houses design. The kind of activities also influence the houses design and it's attributes (e.g size, the type of space). By comparing the attributes of the houses and households' requirements, the design is determined. In which kinds of tourism activities are included in their daily activities.
\end{abstract}

Keywords: coastal housing design, post bridge construction, tourism icon

\section{Introduction}

The coastal area of Kenjeran-Bulak that consists of 521.62 hectares is known as the economically strategic region of Surabaya. This area is potentially developed to be the tourism district for people from local and outside Surabaya. In order to cover this issue, the government of Surabaya decided to build the bridge near fishermen settlements due to increase the function of this area, not only for fishing but also for tourism area. The impact of this construction is some houses were destroyed and rebuilt. The majority of coastal settlements in Surabaya are low income housing which resided by fishermen or people who have activity related with the sea. For this community, a house has a multi-dimensional meaning, it is not just a shelter but also a place to accommodate all of the households' activities, including business. For the next future, this coastal settlement is not only as a shelter for inhabitants but also for tourism icon.

Kenjeran bridge construction certainly causes positive and negative impact to the surrounding community and environment. In short period the negative impact in terms of economy made the decline of people's income which is 
caused by the contamination of the sea water. The sea water contaminated, dredged and backfilled by the bridge materials during the construction and reclamation. As an impact the quality of seawater will decrease and it may cause of the death or the migration of marine life such as fish, shellfish, shrimp. This is certainly causes a decline in fishermen production that will impact to their income.

Besides the negative impact, there are also the positive impacts occur, i.e during and after the construction of the bridge is completed, there will be new employment of these facilities. Surely this can be employment opportunities for residents, both local villagers and those who are not affected by the rearrangement. In addition, other positive impact is to encourage local residents to be more creative in capturing the new business opportunities such as by establishing a centre for souvenirs, foods, or boat rental that aims to revive the tourism areas in the region.

The construction of Kenjeran Bridge requires the development of integrated environment. The integrated planning will be more effective to change the slum. The development should be directly to community empowerment and also touches the needs and character of the local community, so that they will be able to develop their own potential. A fisherman village in the region could become an icon for coastal tourism / travel fishing village. In addition to improving the aesthetics of the region, the development of environment will be able to lift the people's economy. Meanwhile, infrastructure development only serves as a support. Empowerment of society is also required in addition to compensation in the form of materials, with the aim that people can improve their economy to be more independent. Local knowledge of the region of Kenjeran also needs to be maintained. In addition to the presence of the bridge it is expected that the sectors which are previously collapse or have no progress will be more alive.

For this reason, it is necessary to design a comprehensive region particularly with regard to the rearrangement of the fisherman village post Kenjeran bridge construction that favour the comfort of occupants.

\section{Theory of Urban Renewal as an approach for the Region Arrangement}

Urban Renewal approach will be used to describe the arrangement of the affected area that caused by the construction of Kenjeran Bridge. Urban renewal is an effort to re-treatment an area by replacing some or all of the old elements with new elements in order to enhance the vitality and quality of the environment, so that these areas can contribute better to the city as a whole (UU No. 24, 1992). Improving the quality of the environment is a policy on settlements renewal.

Urban renewal is defined as the process of cleaning out the slums and rebuilding physical by taking the values of other elements such as maintenance of heritage (Couch, Sykes \& Boerstinghaus in (Zheng, Shen, \& Wang, 2013)). Urban Renewal is also a way for planners, urban designers and policy makers to intervene in matters of urban space. Urban renewal shows how to develop the built environment. It also becomes an important tool for the country to overcome the physical and social issues related to the built environment, such as a decrease in the quality of urban inequality and imbalance in urban growth, urban disease, and social unrest. Finally, urban renewal becomes important for the regulation of city planning, to create a comfortable environment.

From the definitions above, it can be concluded that urban renewal is an attempt or effort to improve the urban environment that has decreased in terms of the quality either in the physical environment or in the social communities. According to UN-Habitat (2011), Urban Renewal consists of three levels: (1) the macro level that includes a national scale; (2) meso-level that covers regional/city scale; (3) micro level that covers residential neighborhood.

Several other researchers, Djoko Sujarto (Sujarto, 1985: 2), states that the urban renewal can be seen in three scopes, namely as a process, as a function and as a program. As a process, urban renewal is defined as a process of redeveloping the parts of the city that has been built in order to improve the productivity and usability theses city parts. As a function, urban renewal is defined as activities to control, manage and rehabilitate or rebuild a part of the town that has been damaged in order to accommodate activities that are consistent with the existing town plan. As a program, urban renewal may be a part of urban development projects which are implemented in coordinated and integrated manner.

Some of the important factors in urban renewal are economic and non-economic factors. 
a) According to Richardson there are two things that lead to the need for urban renewal effort based on economic factors, namely: poor conditions on housing of the low income people, and the need for a location of commercial activities for housing the upper and middle income community in the city center.

b) The non-economic considerations, according is the result of social benefits in terms of physical improvements, such as improved community health, reduced fire hazard and decreasing crime. In addition, King found other non-economic factor namely the increasing comfort and aesthetic value of a part of the city area that can foster a sense of pride for its citizens.

Good city is a unified system of organization, both socially and visually or physically that are designed in integrated manner. A city is not enough only planned but also to be designed. Urban Design is a bridge between town planning and architectural design, both buildings and spaces outside of them, in three-dimensional which are easy to understand visually.

Urban renewal can be interpreted as one of the approaches in the process of urban plans to restructure an area in the city in order to get a higher / more adequate added-value of the city region in accordance with the potential and economic value which is owned by the region, as quoted Danisworo.

In this study, the definition of urban renewal is physically changes of a city to the buildings and facilities that have been damaged or deteriorated. The changes are made to overcome the pressure due to socio-economic changes. The urban renewal is also a continuous recurring because of the situation in which the population and the needs are always changing.

Urban renewal is the efforts that made to overcome and anticipate the widespread of the negative impact of urban development. In this case urban renewal is done to solve the problem of damage of a region/city that is caused by the development of infrastructure in the surrounding area which includes damage to or deterioration of the quality of the surrounding buildings and environment. It is measured according to the applicable standards, in which building and environmental conditions do not meet the requirements. Although the buildings in the beginning were largely did not meet the eligibility of standards, but with the development of infrastructure (in this case the Kenjeran bridge) it will certainly have an impact on the surrounding environment both positively and negatively, including the degradation of the neighbourhoods. Thus, the rearrangement of the city/region intended here is in order to improve the quality of the region, embellish and beautify that aims to increase / change the function of the area into a tourism area.

\section{Methods and Strategy}

In terms of method, this study was design as an explorative, descriptive, ex-poste and evaluation study. By using an in-depth interviews method, the idea, hope, expectation of inhabitants was gained. 30 respondents were taken from sub-districts surrounding the bridge. The village is Sukolilo. The respondents came from the community groups that were affected, ie the fishermen and the home industry entrepreneurs.

The first step is to identify and classify the problems arising from the construction of this bridge. The next step is to give the proposals in accordance with the expectations of society and the problems that were identified. Then it is continued with processing and analyzing the data and finalized by making the proposed restructuring plan of the fishermen residential areas that were affected. The results of the regional rearrangement plan will be communicated to the public and the government.

\section{Aims, Uses, and Expected Impact}

The purpose of this service is to provide input to the Surabaya city government, and to the communities who were affected by the construction of Kenjeran bridge to obtain positive feedback related to the rearrangement of the fisherman settlement. Benefits to be derived are:

1. Provide feedback to turn this fisherman settlement becomes a strategic location and has attractiveness in order to invite the attention of tourists to visit the village/region. Produce clear and comprehensive information about the impact of development on the community, as well as solutions and rearrangement to the affected area. 
2. The impact that is expected from this activity is the awareness and supports of the community and the city government of Surabaya in the arrangement and structuring of coastal residential area of Surabaya, in this case the area around the Kenjeran bridge.

\section{Policy and Strategic Plan of the Government on the Area of Study}

Sukolilo village, the area of this study, is planned to remain as a fisherman settlement with the concept of "Climate Village" (Kampong Iklim) where community members are required to improve their neighbourhood independently by attending to the environmental sustainability. The territory of this study is the Development Unit 3 that covers marine tourism, development of natural and artificial tourism, fishing area \& aqua culture, and shipping lanes of the fishing boats.

The location of study areas includes Kelurahan Sukolilo RW I, RW II and RW III as shown below:

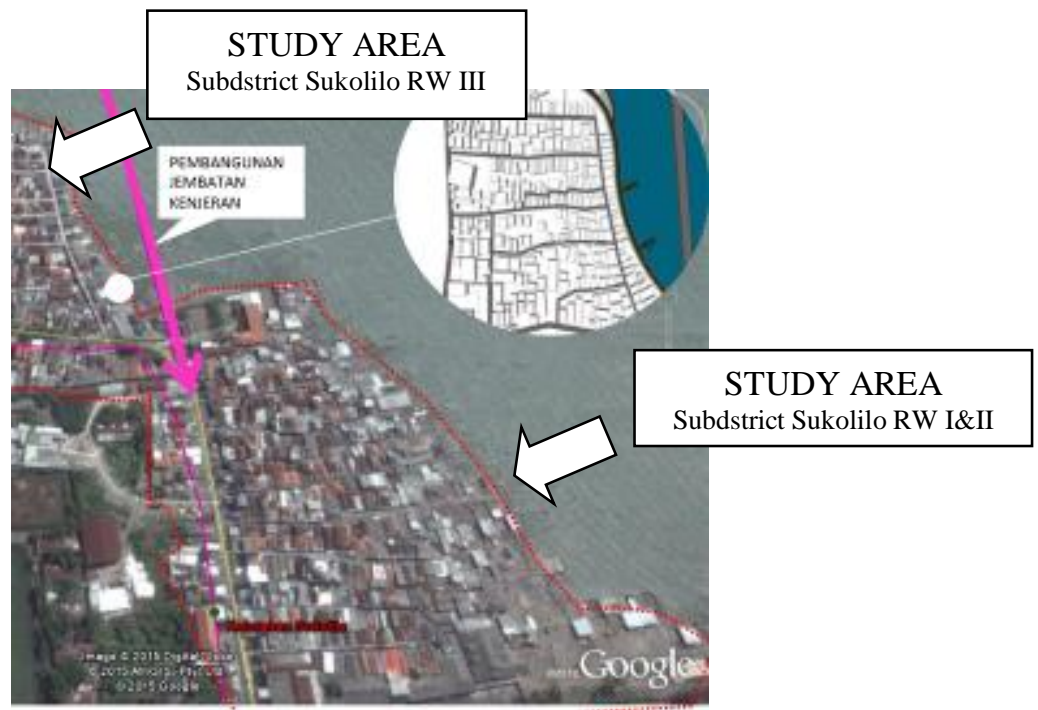

Fig. 1: Location of Study objects. Source: Bappeko Surabaya

The study region is a fisherman village which in the future remains as a fishing village with a number of strategic plans for its development including as "climate village". Kampong Iklim is a prototype of kampong that developed by the government together with the community which is patterned as excelled kampong, and is based on smart village. This pattern requires its community to role actively in the management of the village.

The concept that offered by the government is an integrated sanitation management as shown below: 


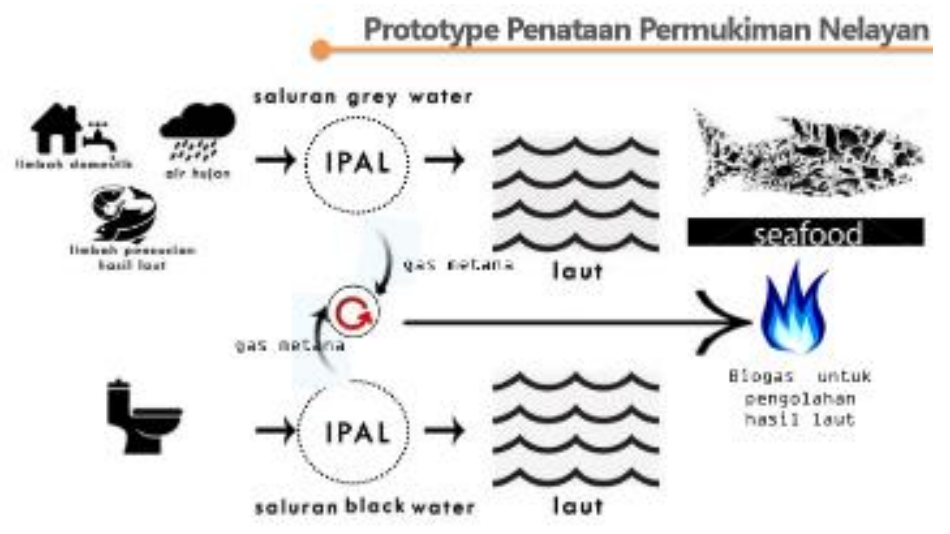

Fig. 2: the Integrated Sanitation Management that offered by the government. Source: Bappeko Surabaya

Sanitation systems are planned centrally and located near the sea, both that derived from the gray water and from the black water. The resulting methane gas is processed so that it can be used for cooking fuel. Here exists the management of energy which is obtained from the processed waste. After having been processed, then the results of WWTP (IPAL) will be discharged into the sea. As this section is not yet planned by the government, this study focuses on the providing of "climate town" in the Village of Sukolilo.

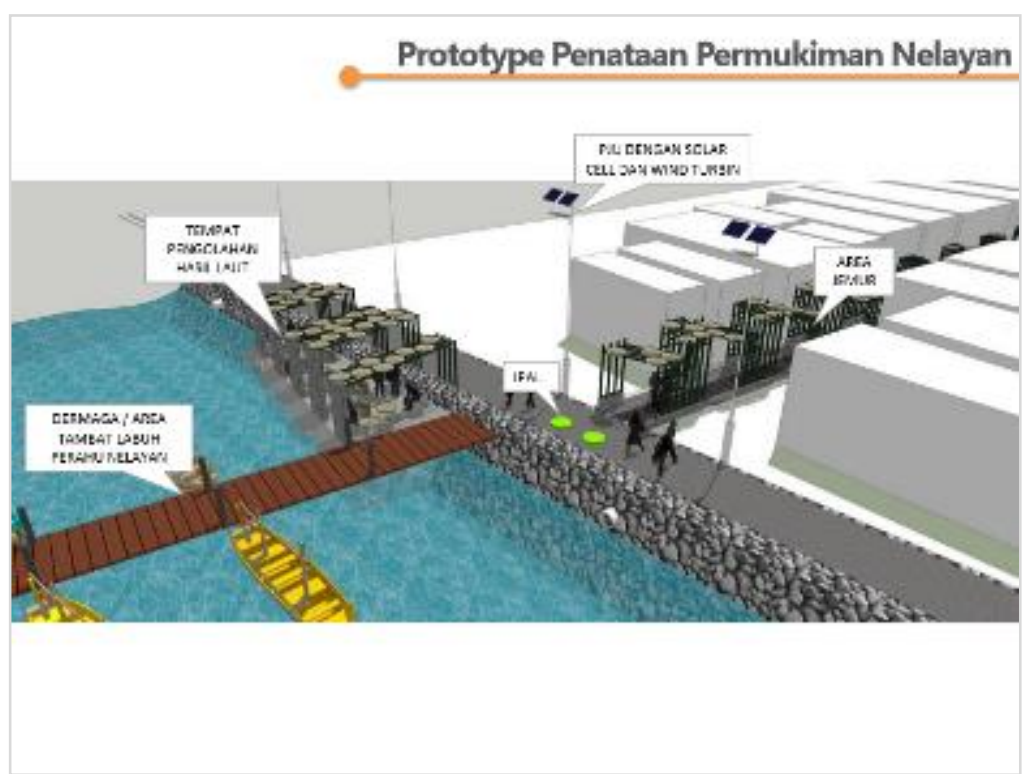

Fig. 3: Prototype of the Structuring of Fisherman Village. Source: Bappeko Surabaya

\section{Problems and Suggestions for Solution}

Some of the problems that are derived from the field studies: 
1. Some residents are fishermen who catch fish and sell seafood or residents who have business on processing and selling processed seafood (businessmen / traders of crackers of marine products, manufacturer/seller of craft shells, etc.) so that the availability of land for sunning/drying the sea products are urgently required. During these time residents did it over/on the drains or on the roadside. After demolition and road widening were made by the government, these activities could no longer be done by the citizens. In addition, the places for direct selling the fish (the fish auction place), are not available either in this village. So the absence of the drying place and the public auction causes them to sell their fish catchment directly to the skipper (middlemen), so they just get their sale results at very low price.

2. The location of Bulak Sentra of fish sales are still considered too far by the people who sell the processed products. The position is also considered not strategic because it is too far from their settlements, so that mobility of residents is difficult. Besides, the lack of promotion led to the lowness of buyer. This is also the reason why the citizens are reluctant to sell their merchandise there. Residents hope that the government could provide a place for the sale of processed products which are not too far from their houses. In addition, the extent of the available stalls that are considered too narrow is also an obstacle. They hope that the area of the shared stalls can be widened, from initially $2 \times 3$ meters is widened to $3 \times 4$ meters.

3. Residents mainly the fishermen find it difficult to mobilize because the construction of road limits their village with the Kenjeran bridge. This road separates the village to the sea and there is no access for the boat to get through it. This causes citizens to feel the difficulty which impact on the lack of their income.

4. The catchment of fish is declined and the sea is perceived further is the consequence of this Kenjeran bridge construction, so that some fishermen do not go to fish to the sea again, but switched their professions to become tenants of boat to serve tourists who want to get around the beach and the surrounding area.

5. Waste management is not good due to a lack of awareness of the people causing a condition being a polluted environment. This is compounded by the habits of citizens who backfill the sea with rubbish for their residence expansion in order to minimize the soil.

6. The conditions of village which is slum and un-maintained causing residents to feel less worthy to be a marine tourism destination "Fisherman village". But they do not want to be relocated or moved to new residential flats. The reason is that the relocation would deprive them from their livelihood which is catching fish in the sea, and being on flats, will make them having difficulty in drying fish and mooring boat. The only proposal of them is to improve their village by patterns of Kampung Improvement Program (KIP).

From the problems found in the field above, several alternatives of solutions are proposed by considering the field conditions, relevant local regulations and the wishes of citizens:

1. The lack of land at the site of the study led to constraint of effort to provide a place for drying fish/seafood/processed product (crackers). However, this can be anticipated by draining off-shore together, which location is integrated with the Sentra Sales of fish or supply of automatic fish dryer.

2. The presence of Kenjeran bridge (Bridge Surabaya) could become a new tourism icon to attract tourists. Especially during the school or major holidays and weekends. The existence of children's playground can also be one of the destinations for supporting the centres of fish industry. So it is expected that the fewness of visitors will not happen again in the future.

3. Kampung improvement Program is highly recommended considering that the program is the most likely desired to apply with no refusal and limited funds. Improved infrastructure, particularly for: roads, water and sanitation are the main objective of this program. Empowerment of citizens to build their village becomes the centre of activities to support the success of this program.

4. The need of integrated management for solid waste at the site of the study. Not only provided the trash, but also its management. It can be cultivated in every RW. The most difficult RW is RW1 and RW2 due to a lack of their public awareness. In RW 3 namely Sukolilo village, it is already running well but it still needs to be improved.

5. Kampung Improvement is pursued to be the improvement of its stimulus. Repairs are performed only for the improvement of the infrastructure, especially for pedestrian, water and sanitation. With the increasing quality of the environment, the economy of residents is expected to trigger an increase. Home repairs should be made by the community itself. 


\section{Discussion}

With the concept of climate village above, some proposals may be submitted as described below. This proposed regional renewal provides guidance for the design of the rearrangement of the area. The guidelines for the design of the area are:

1. The provision of facilities for waste in the study locations and its management should be integrated. Household waste bins remain in each family unit. It is recommended that the trash cans are made easily removed and transferred, to be easily moved and cleaned. Separation system between organic and non-organic garbage should be done from the beginning. At each end of the alley there should be a communal bin to allow waste collection from each household unit. From this communal trash transfer can be continued to Temporary Disposal (TPS) by the communities themselves.

2. The improvement of the kampung infrastructure should be done by adopting the idea how the KIP program was conducted. This program empowers and involves a lot of citizens in its implementation. So that the control of citizens as well as their sense of belonging could be stronger as they get involved.

3. Sanitation in the form of processing of household waste coming from the WC and the bathroom should be made centralized to make it more efficient, and the result of process in the form of methane gas, can be utilised. Waste Water Treatment Plant (WWTP) both gray and black water is done communally at each end of the alley (near the sea). It is estimated approximately $40-50$ households. Once the process of waste water treatment runs, the result in the form of methane (CH4) is administered into fuel for seafood processing centres which are located in every region. This Sentra should also exist in every alley.

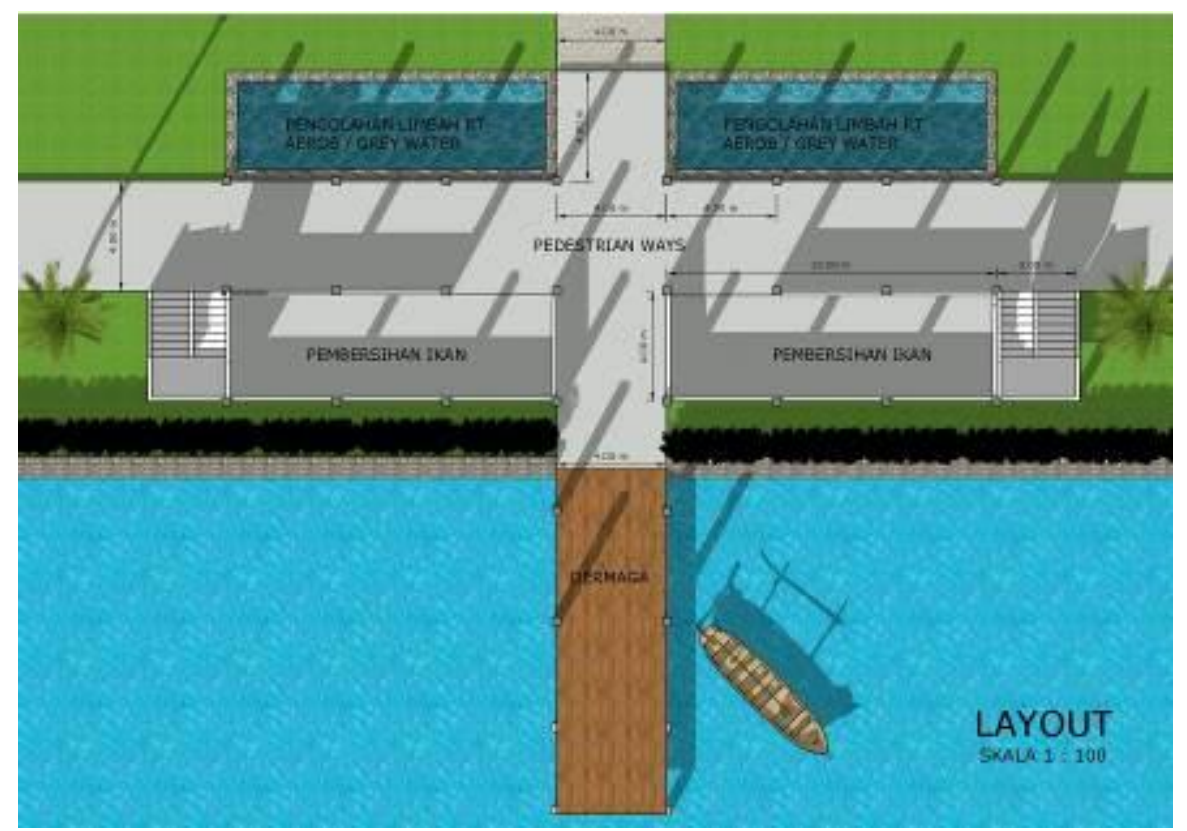

Fig. 4: The Layout 


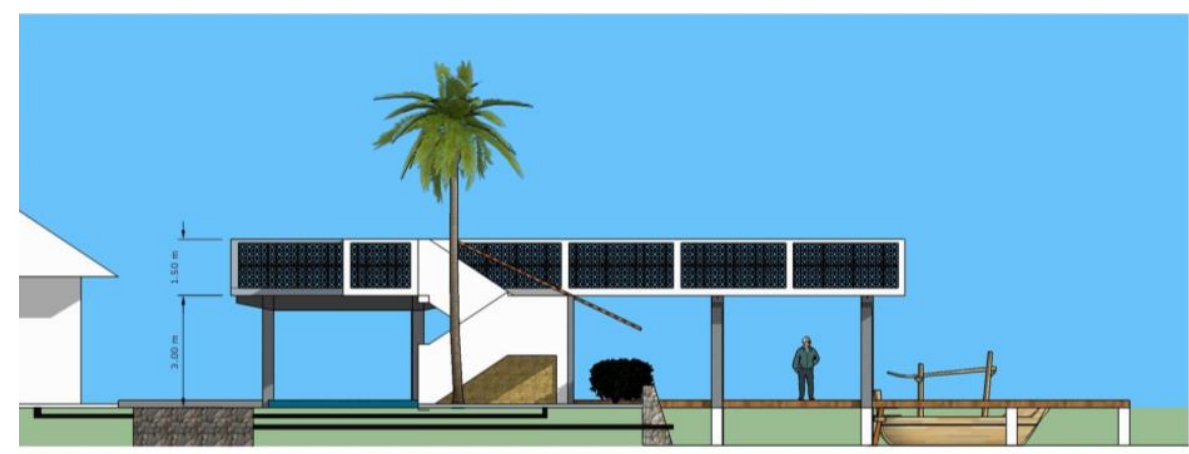

TAMPAK SAMPING

Fig. 5: The Side Elevation

4. The results of the processing in the form of effluent should be lowered its BOD (Biological Oxygen Demand) values, by organic crops which serves to reduce effluent BOD value, before being discharged into a body of water (ocean).

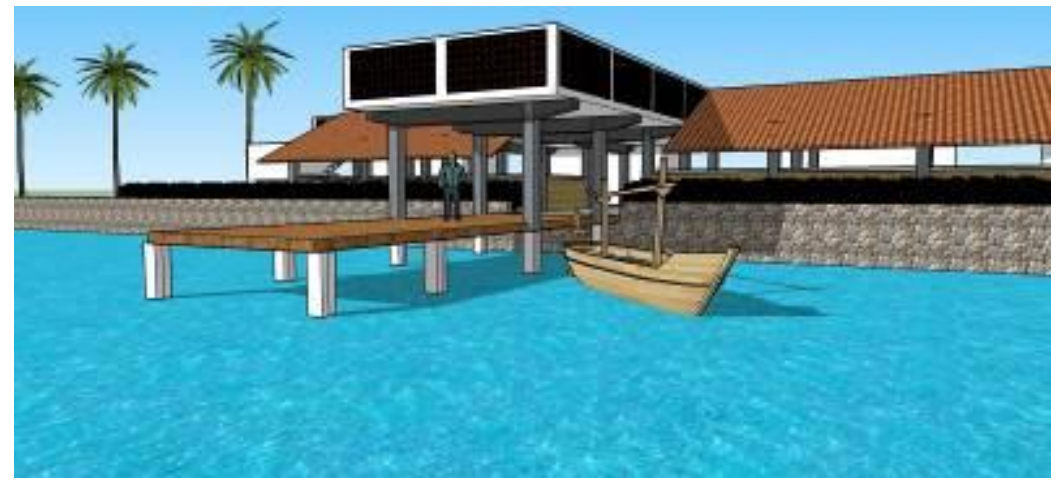

Fig. 6: Mooring of Boats or Jetty

5. Anchoring of boats should be performed on every aisle so it is not to complicate the work of fishermen as well as fishermen who rent their boats. Dock should be made jutting into the sea with a quay length suited to the number of boats that exist in every alley. Realignment of the boat mooring location is intended in order not to disrupt fishermen in renting their boats as the existence of the new road separates their village from the sea. 


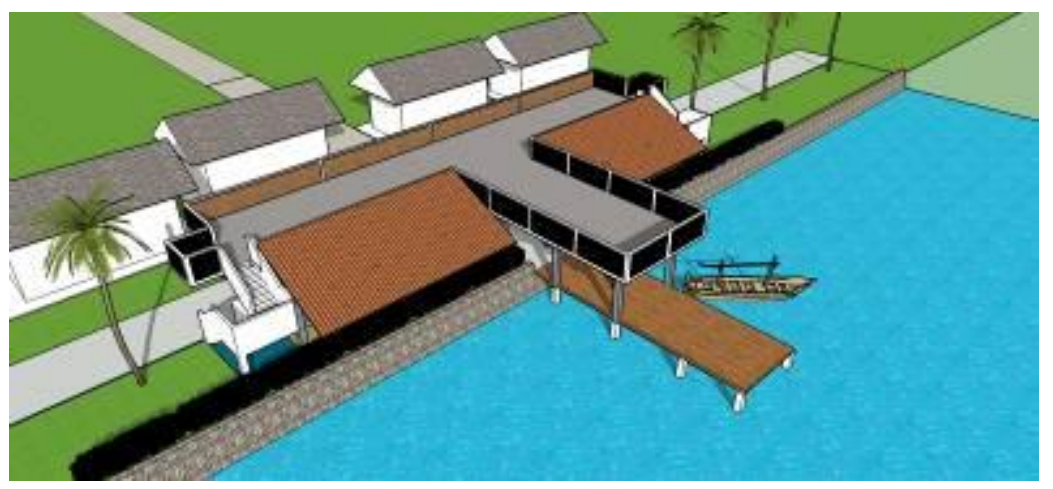

Fig. 7: The Bird Eye View

6. Facilities of boat mooring also provide a place for waiting which is adequately shaded. This dock facility / boat pavilion is made artistically that aims to attract domestic and foreign tourists.

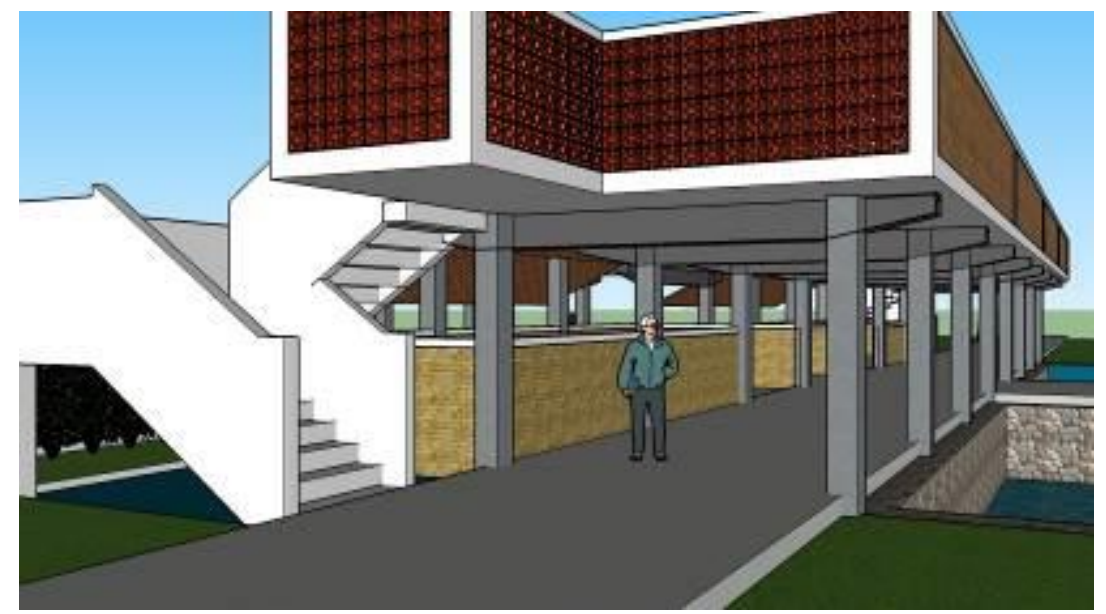

Fig. 8: the Shaded Waiting Place

7. The boat anchoring or the jetty, which was located in RW 3, was built after the construction of Surabaya bridge. However, the public were given an access to enter through the inspection street that has been built before. The drying space of marine products and the results of processed products were made above along every aisle. So the space held is not decreased, but the drying space is increased.

8. Because of the limited land, provision of places for drying fish could be in off shore or integrated with the fish sale centres or near the settlements by utilizing the existing space above the alley. 


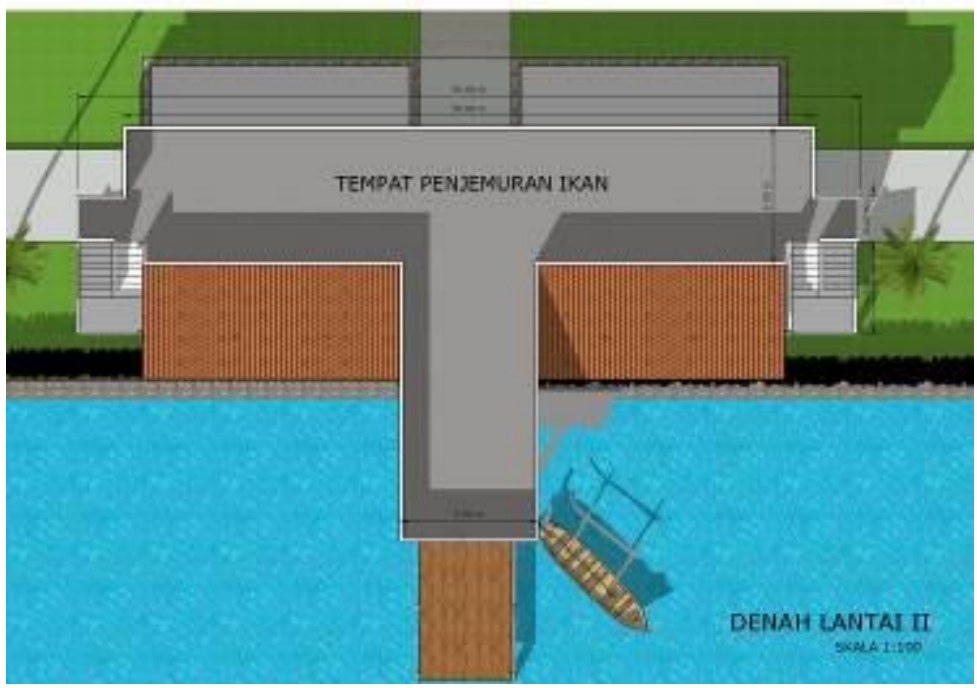

Fig. 8: Plan of second floor

9. Drying is conducted by utilizing solar heat which is reflected from the base of the drying place which is in dark colour, so that it absorbs the sun's heat that can be used to dry the product without the need to reverse. To be more hygienic, the upper part of the dried products is given plastic cover which is designed to be a good reflector of the light anyway

\section{References}

UU No. 24. Undang-Undang Tentang Penataan Ruang (1992).

Zheng, H. W., Shen, G. Q., \& Wang, H. (2013). A review of recent studies on sustainable urban renewal. Habitat International, 41, $272-279$. https://doi.org/10.1016/j.habitatint.2013.08.006 